\title{
Study on Fuel Specificity and Harmful Air Pollutants Factor of Agglomerated Wood Charcoal ${ }^{1}$
}

\author{
Taek Yong $\mathrm{JEOUNG}^{2} \cdot$ Seung $\mathrm{Min} \mathrm{YANG}^{2} \cdot \operatorname{Seog}$ Goo $\mathrm{KANG}^{2, \dagger}$
}

\begin{abstract}
This study selected three types of agglomerated wood charcoal (Agglomerated wood charcoal with charcoal powder, Carbonized wood briquette, Ignition-type of perforated charcoal) that are in circulation in Korea among fuel-type wood products and analyzed the fuel characteristics, harmful substance content, and emissions of air pollutants generated by combustion. The first results showed that charcoal-grilled carbon, which is the raw material of charcoal, produced higher CO than saw-billed carbon. The second result is that the emission standards of air pollutants generated by the combustion of molded wood coal are not up to the emission standards of nitrogen oxides and sulfur oxides in the entire product, compared with the emission criteria of the atmospheric environment preservation method (based on 2019, carbon monoxide: 200 ppm, nitrogen oxides, 150 ppm sulfur oxides: $100 \mathrm{ppm}$ ), but the carbon dioxide moulding and carbon dioxide levels were not up. Based on the analysis of combustion gas generated during combustion derived from this study, future research is needed for comparing with the emission standards of pellets, which are wood products for fuel, among the existing biomass burning standards and for reducing carbon monoxide generated during incomplete combustion of agglomerated wood charcoal.
\end{abstract}

Keywords: renewable energy, air pollutants $\left(\mathrm{CO}, \mathrm{CO}_{2}, \mathrm{NO}_{\mathrm{x}}, \mathrm{SO}_{\mathrm{x}}\right)$, agglomerated wood charcoal

\section{INTRODUCTION}

Recently, there has been increasing public interest in fine dust and pollutants entering in the atmosphere of Korea (Jo et al., 2019). The Ministry of Environment amended and promulgated the Enforcement Regulations of the Clean Air Conservation Act in May 2019, and planned to implement it in January 2020. According to the amended enforcement regulations, substances such as ethylbenzene, styrene, and carbon tetrachloride have been newly established as specific air pollutants, and the regulations on existing specific air pollutants
(13 types including chromium, arsenic, mercury, etc.) have been strengthened by approximately 33\%. For 11 types of general air pollutants (dust, carbon monoxide, nitrogen oxides, sulfur oxides, etc.), the standards on allowable emission have been reduced by an average of 30\% (Magnone et al., 2019).

As the standards on allowable emission of pollutants have been strengthened, companies have established air pollutant emission reduction devices, and coal power plants came up with alternatives such as an indoor coal yard (an indoor coal yard project to reduce scatter dust from outdoor coal yards) and the use of renewable

${ }^{1}$ Date Received September 17, 2019, Date Accepted March 9, 2020

2 Deparment of Biobased Materials, College of Agriculture and Life Science, Chungnam National University, Deajeon 34134, Republic of Korea

† Corresponding author: Seog-goo KANG (e-mail: lachesis@cnu.ac.kr, ORCID: 0000-0002-2440-7070) 
energy sources such as wood pellets, etc (Kang et al., 2018; Yang et al, 2018). Recently, research on the use of resources such as mixed solid fuels including waste wood and spent carbon has been conducted to study fuel-type wood products, which include agglomerated wood charcoal, as it is in increasing demand in Korea due to an increasing number of campers (Kwon et al., 2010; Lee et al., 2015). However, frequently there has been cases in which harmful gases such as benzene, toluene, and carbon monoxide generated when waste wood prohibited in such fuel-type wood products is used (Kwon et al., 2018; Yang et al., 2018; Edoard et al., 2019).

In order to prevent this, in accordance with Article 14, Paragraph 1 of the Enforcement Decree of the "Law on Sustainable Use of Wood", the Korea Forest Service has been implementing administrative and judicial procedures for quality compliance by inspecting 15 types of wood products through continuous crackdown and product testing. In particular, the quality of fuel-type wood products such as wood pellets and agglomerated wood charcoal are evaluated according to the heavy metal content and calorific value included in the product, which are items in the current quality standards (Lee et al., 2017). However, the revised regulations not only strengthened the standards for restricting air pollutant emissions, but also included biomass burning (meat and fish roast, open-air incineration, wood stove, charcoal kiln, etc.), which is a comprehensive term that refers to biomass burning among air pollutant emission sources specified in 2011.

During biomass burning, not only various particulate and gaseous air pollutants are emitted, but also greenhouse gases such as carbon dioxide, methane, and nitrous oxide are discharged on a large scale (Kim, 2011). There is an increased interest from the public in the air pollutants emitted during charcoal combustion, which occurs frequently in restaurants and camping sites, and there are studies on the emission of fine dust due to roasting (Park et al., 2011).

However, there have been few studies on air pollutants generated during combustion of fuel-type wood products such as agglomerated wood charcoal and wood pellets. In particular, research on fuels based on wood is at best about reducing air pollutant generation during incineration of waste wood and calculating annual average greenhouse gas emissions by tree species and products for charcoal (Kim et al., 2010; Seo et al., 2015; Yang et al., 2017).

At a time when the importance of strengthening air pollution emission standards and biomass burning is emphasized, this study aims to compare and analyze the quality characteristics among the agglomerated wood charcoal products distributed in Korea and the emissions of air pollutants $\left(\mathrm{CO}, \mathrm{NO}_{\mathrm{x}}, \mathrm{SO}_{\mathrm{x}}\right)$ generated during combustion, in an attempt to prepare emission standards for air pollutants from agglomerated wood charcoal.

\section{MATERIALS and METHODS}

\subsection{Testing materials}

The test materials used in this study are three types of agglomerated charcoal distributed in Korea in ac-

Table 1. Species of raw materials about test pieces of agglomerated wood charcoals

\begin{tabular}{|c|c|c|c|}
\hline & \multicolumn{3}{|c|}{ Type of agglomerated wood charcoal } \\
\hline & Char & al B & al $\mathrm{C}$ \\
\hline \multirow{2}{*}{$\begin{array}{l}\text { specie of raw } \\
\text { materials }\end{array}$} & $\begin{array}{l}\text { Mixed Hard } \\
\text { wood }\end{array}$ & Merbau & $\begin{array}{l}\text { Mixed Hard } \\
\text { wood }\end{array}$ \\
\hline & occ & & wood \\
\hline \multicolumn{4}{|c|}{$\begin{array}{l}\text { * Charcoal A - agglomerated wood charcoal powder, } \\
\text { Charcoal B - agglomerated wood charcoal sawdust, } \\
\text { Charcoal C - agglomerated wood charcoal for igniting } \\
\text { nine-holed charcoal } \\
\text { * Charcoal B (agglomerated wood charcoal sawdust) has } \\
\text { no domestic producer, so both samples are imported. } \\
\text { * Charcoal C (agglomerated wood charcoal for igniting } \\
\text { nine-holed charcoal) has no imported samples, so both } \\
\text { samples are domestic products. }\end{array}$} \\
\hline
\end{tabular}


cordance with the specifications and quality standards of wood products (No. 2018-8). They were classified into 4 types of lumber industry (domestic production) and wood import distribution business (import) for tree species. Specified types of Agglomerated wood charcoal specimens are shown in the Table 1. Charcoal A (Mixed Hard wood) is obtained from Homebeque Inc., Charcoal A (Coconut shell) from Juwon System, Charcoal B (Merbau) from Shinil Energy, Charcoal B (Bamboo) from Wooae Hardwood Charcoal Korea Inc., Charcoal C (Mixed Hard wood) from Yongmoon Industry, and Charcoal C (Mixed wood) from Daemyung Charcoal Inc.

\subsection{Experimental methods}

\subsubsection{Fuel specificity of the test piece}

The calorific value, fixed carbon, and volatile matter were analyzed to compare the fuel specificity of the test materials, and Bomb calorimeter (Parr 6400, PARR INSTRUMENT INC, USA) was used to measure the high heat generation by using dry raw materials. The components of moisture, volatile matter, ash, and fixed carbon were analyzed in accordance with KS F 3705 (industrial analysis method of coals and cokes). An automatic elemental analyzer (Flash 2000, Thermo SCIENTIFIC, USA) was used to analyze the carbon and hydrogen composition of the test piece.

\subsubsection{Content of harmful substances in the test piece}

To predict air pollutants emitted to the atmosphere during agglomerated wood charcoal combustion, 8 kinds of heavy metals, which are harmful substances in products contained in the test piece, and small amounts of harmful substances, such as barium nitrate, were analyzed using inductively coupled plasma spectrometers (JP/ICPE-9820, Shimadzu, Japan). As a pre-treatment method, the sample is screened with 0.25 $\mathrm{g}$ of particles less than 40 mesh $(0.25 \mathrm{~mm})$, diluted with distilled water of $70 \%$ nitric acid solution by 240 times the sample weight, and pre-treated with temperature rising for 30 minutes and maintaining the temperature at $170^{\circ} \mathrm{C}$ for 30 minutes using a microwave decomposition system (Microwave, Multiwave PRO, Anton Parr, Austria). Since the experiment was carried out with a small amount of sample $(0.25 \mathrm{~g})$, all the samples were dissolved without leaving residuals.

\subsubsection{Amount of air pollutants generated by the test piece}

In order to compare the air pollutants generated during the combustion of agglomerated wood charcoal products, a commercially available $40 \times 40 \times 80 \mathrm{~cm}$ briquette furnace, as shown in Fig. 1, was selected and used to burn the actual materials. A test piece of 330 $\mathrm{g}$ was installed inside the furnace. Then, from the time of ignition (igniting temperature of $250^{\circ} \mathrm{C}$ ), air pollutants (ppm, \%) discharged during the ignition measurement time of 60 minutes were measured in accordance with the specifications and quality standards of wood products (No. 2018-8). At this time, the air pollutants were measured in terms of $\mathrm{CO}, \mathrm{NO}_{\mathrm{x}}$, and $\mathrm{SO}_{\mathrm{x}}$, using a portable combustion flue gas analyzer (GreenLine MK2, EUROTRON s.r.l, Italy).

\section{RESULTS and CONSIDERATIONS}

Two types of agglomerated wood charcoal distributed in Korea were selected to measure the quality characteristics of the product and the amount of air pollutants emitted during combustion. Quality inspection was carried out

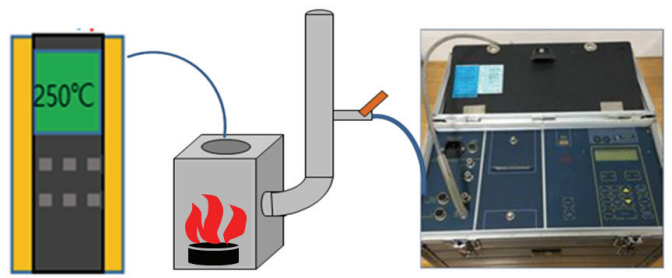

Fig. 1. Exhausting gas test. 
according to the standard quality standards of wood products in Table 3. The air pollutant emission criteria shown in Table 4 were compared with the amount of air pollutants generated during the combustion of agglomerated wood charcoal, and the result was deducted.

\subsection{Fuel specificity of the test piece}

The results of calorific value, fixed carbon, volatile matter, and elemental analysis achieved by a test method according to supplement 14 among the specifications and quality standards of wood products (No. 2018-8) are shown in the Table 2. Among the agglomerated wood charcoal products, Charcoal A (Mixed Hard wood), Charcoal B (Mixed Hard wood), and Charcoal $\mathrm{C}$ (Mixed wood) have an ash content of more than $30 \%$ and a fixed carbon content of less than $42 \%$. It is assumed that the ash content is high because it was molded using raw materials under the conditions in which substances, such as soil, introduced in the production process were not removed. In addition, Charcoal
B of two species, which have the lowest moisture content and ash content of less than $10 \%$ and the highest heat generation quality of greater than $7,600 \mathrm{kcal} / \mathrm{kg}$, has excellent fuel specificity, since its raw materials are tropical tree species of Merbau and Bamboo (Jang et al., 2017). Through experiments, the high heat generation amount and the fixed carbon content of the agglomerated wood charcoal appeared to have a proportional relationship. This is probably because the higher the carbonization degree during the carbonization process, the less the volatile matter, and the more fixed carbon content and ash content of residual minerals, which have an inversely proportional relationship (Lee et al., 2015). Also, the higher fixed carbon content is indicated with the higher calorific value. This is because the total weight of the sample can be calculated as the sum of volatilization (volatile matter) and char reaction (fixed carbon deformation), moisture evaporation (moisture content), and ash (residual ash) (Lee et al., 2000). Because hydrogen and oxygen contents are reduced, it is closely related to the carbonization of raw materials (Jo et. Al., 2006). In the case of Charcoal

Table 2. Standard of specification quality inspection about agglomerated wood charcoal

\begin{tabular}{cccc}
\hline \multirow{2}{*}{ Property } & \multicolumn{3}{c}{ Standard of specification quality } \\
\cline { 2 - 4 } & Charcoal A & Charcoal B & Charcoal C \\
\hline \hline Moisture content(\%) & Under $10 \%$ & Under $10 \%$ & Under $10 \%$ \\
Ash $(\%)$ & Under $25 \%$ & Under $10 \%$ & Under $17 \%$ \\
High heating valve(kcal $/ \mathrm{kg})$ & Over $4,200 \mathrm{kcal} / \mathrm{kg}$ & Over $6,500 \mathrm{kcal} / \mathrm{kg}$ & Over $5,500 \mathrm{kcal} / \mathrm{kg}$ \\
Fixd carbon(\%) & Over $30 \%$ & Over $65 \%$ & Over $50 \%$ \\
$\mathrm{As}(\mathrm{mg} / \mathrm{kg})$ & Under $3.0 \mathrm{mg} / \mathrm{kg}$ & Under $3.0 \mathrm{mg} / \mathrm{kg}$ & Under $3.0 \mathrm{mg} / \mathrm{kg}$ \\
$\mathrm{Cd}(\mathrm{mg} / \mathrm{kg})$ & Under $1.5 \mathrm{mg} / \mathrm{kg}$ & Under $1.5 \mathrm{mg} / \mathrm{kg}$ & Under $1.5 \mathrm{mg} / \mathrm{kg}$ \\
$\mathrm{Cr}(\mathrm{mg} / \mathrm{kg})$ & Under $30 \mathrm{mg} / \mathrm{kg}$ & Under $30 \mathrm{mg} / \mathrm{kg}$ & Under $30 \mathrm{mg} / \mathrm{kg}$ \\
$\mathrm{Cu}(\mathrm{mg} / \mathrm{kg})$ & Under $30 \mathrm{mg} / \mathrm{kg}$ & Under $30 \mathrm{mg} / \mathrm{kg}$ & Under $30 \mathrm{mg} / \mathrm{kg}$ \\
$\mathrm{Pb}(\mathrm{mg} / \mathrm{kg})$ & Under $30 \mathrm{mg} / \mathrm{kg}$ & Under $30 \mathrm{mg} / \mathrm{kg}$ & Under $30 \mathrm{mg} / \mathrm{kg}$ \\
$\mathrm{Hg}(\mathrm{mg} / \mathrm{kg})$ & Under $0.15 \mathrm{mg} / \mathrm{kg}$ & Under $0.15 \mathrm{mg} / \mathrm{kg}$ & Under $0.15 \mathrm{mg} / \mathrm{kg}$ \\
$\mathrm{Ni}(\mathrm{mg} / \mathrm{kg})$ & Under $30 \mathrm{mg} / \mathrm{kg}$ & Under $30 \mathrm{mg} / \mathrm{kg}$ & Under $30 \mathrm{mg} / \mathrm{kg}$ \\
$\mathrm{Zn}(\mathrm{mg} / \mathrm{kg})$ & Under $300 \mathrm{mg} / \mathrm{kg}$ & Under $300 \mathrm{mg} / \mathrm{kg}$ & Under $300 \mathrm{mg} / \mathrm{kg}$ \\
$\mathrm{S}(\%)$ & Under $15 \%$ & Under $15 \%$ & Under $15 \%$ \\
$\mathrm{Ba}(\%)$ & Under $30 \%$ & - & -
\end{tabular}


A (Coconut shell), the carbon (\%) content of elemental analysis is lower than the fixed carbon (\%) content. That is probably because in the elemental analysis process, the sample in the dry state was analyzed, whereas in the process of industrial analysis, the sample was analyzed in the non-dry state, resulting in the carbon element reversal phenomenon of the fixed carbon due to the difference in moisture content of $20.8 \%$.

\subsection{Content of harmful substances in the test piece}

The results of the content of heavy metals, barium nitrate, etc., that are contained in the test piece are shown in the Table 3 . In contrast to Table 4 , the $\mathrm{Cu}$ content in Charcoal $\mathrm{A}$ and Charcoal $\mathrm{C}$ and $\mathrm{Pb}$ content in Charcoal A (Coconut shell) exceeded the reference values. This seems clear from the detection of trace amounts of heavy metals above the standard values that may occur during the process of producing agglomerated wood charcoal and material pre-treatment. For all other products, $\mathrm{As}, \mathrm{Cd}$, and $\mathrm{Hg}$ were not detected and $\mathrm{Ni}$ and $\mathrm{Zn}$ were below the standard values. The reason why $\mathrm{Ba}(\%)$ was detected in two species of Charcoal $\mathrm{A}$ is that barium nitrate within $30 \%$ of the weight of the charcoal sample is added to promote initial combustion due to the characteristics of agglomerated wood charcoal powder (charcoal A).

Table 3. Emission of allowance standard about air pollutants (Source with The law of Atmospheric environment enforcement regulation on an asterisk 8)

\begin{tabular}{ccc}
\hline Air pollutant & Facility of air pollutant & Emission of allowance standard \\
\hline \hline $\mathrm{CO}$ & Facility of using Biomass or wood pellet & Under $200 \mathrm{ppm}$ \\
$\mathrm{NO}_{\mathrm{x}}$ & Facility of using Biomass or wood pellet & Under $150 \mathrm{ppm}$ \\
$\mathrm{SO}_{\mathrm{x}}$ & Facility of manufacturing SRF & Under $100 \mathrm{ppm}$ \\
\hline
\end{tabular}

Table 4. Results of specification quality inspection about agglomerated wood charcoal

\begin{tabular}{cccccccc}
\hline Test details & $\begin{array}{c}\text { Moisture } \\
\text { content } \\
(\%)\end{array}$ & $\begin{array}{c}\text { Ash } \\
(\%)\end{array}$ & $\begin{array}{c}\text { Fixed carbon } \\
(\%)\end{array}$ & $\begin{array}{c}\text { Volatile } \\
(\%)\end{array}$ & $\begin{array}{c}\text { Higher } \\
\text { heating value } \\
(\mathrm{kcal} / \mathrm{kg})\end{array}$ & $\begin{array}{c}\text { Carbon } \\
(\%)\end{array}$ & $\begin{array}{c}\text { Hydrogen } \\
(\%)\end{array}$ \\
\hline \hline $\begin{array}{c}\text { Charcoal A } \\
\text { (Mixed Hard wood) }\end{array}$ & 2.9 & 36.9 & 30.8 & 29.4 & 3,673 & 79.11 & 2.58 \\
$\begin{array}{c}\text { Charcoal A } \\
\text { (Coconut shell) }\end{array}$ & 20.8 & 4.7 & 67.0 & 7.5 & 6,662 & 54.24 & 0.79 \\
$\begin{array}{c}\text { Charcoal B } \\
\text { (Merbau) }\end{array}$ & 4.7 & 3.2 & 85.4 & 6.7 & 7,721 & 85.02 & 0.69 \\
$\begin{array}{c}\text { Charcoal B } \\
\text { (Bamboo) }\end{array}$ & 8.3 & 3.4 & 81.7 & 6.6 & 7,636 & 88.03 & \\
$\begin{array}{c}\text { Charcoal C } \\
\text { (Mixed Hard wood) }\end{array}$ & 5.9 & 31.7 & 42.1 & 20.3 & 5,460 & 55.72 & 1.84 \\
$\begin{array}{c}\text { Charcoal C } \\
\text { (Mixed wood) }\end{array}$ & 5.3 & 30.9 & 39.3 & 24.5 & 4,563 & 56.22 & 2.86 \\
\hline
\end{tabular}

* In case of Charcoal A(Coconut shell), moisture content is too high than others. Because its state was very wet with oily liquid.

* Charcoal A - agglomerated wood charcoal powder, Charcoal B - agglomerated wood charcoal sawdust, Charcoal C -agglomerated wood charcoal for igniting nine-holed charcoal 


\subsection{Amount of air pollutants generated by the test piece}

\subsubsection{Amount of carbon monoxide (CO) generated by the test piece}

The results of the comparison of carbon monoxide and carbon dioxide emissons according to the type of agglomerated wood charcoal are shown in Fig. 2. The average hourly rate of $\mathrm{CO}$ generation is $0.0615 \%$ (615ppm) (Mixed Hard wood), and 0.0433\% (433ppm) (Coconut shell) for Charcoal A, 0.0279\% (279ppm) (Merbau) and $0.017 \%$ (170ppm) (Bamboo) for Charcoal $\mathrm{B}$ and $0.0586 \%$ (586 ppm) (Mixed Hard wood) and $0.0589 \%$ (589 ppm) (Mixed wood) for Charcoal C. As shown in Table 5, two species of Charcoal A are complexing agents that form an explosive mixture when mixed with organic substances, and barium nitrate is agitated, resulting in lower $\mathrm{CO}$ emissions due to higher complete combustion than Charcoal C. Since the moisture content of Charcoal A (Coconut shell) is $20.8 \%$, which is higher than that of Charcoal A (Mixed Hard wood), it can be confirmed that it takes more time to ignite by the increasing $\mathrm{CO}$ generation, which shows a difference in average $\mathrm{CO}$ generation with low volatile matter content of $7.5 \%$. In the case of two species of Charcoal B, CO emissions were significantly less than Charcoal A and Charcoal C. This is because the fixed carbon in Charcoal $\mathrm{B}$ has a higher proportion

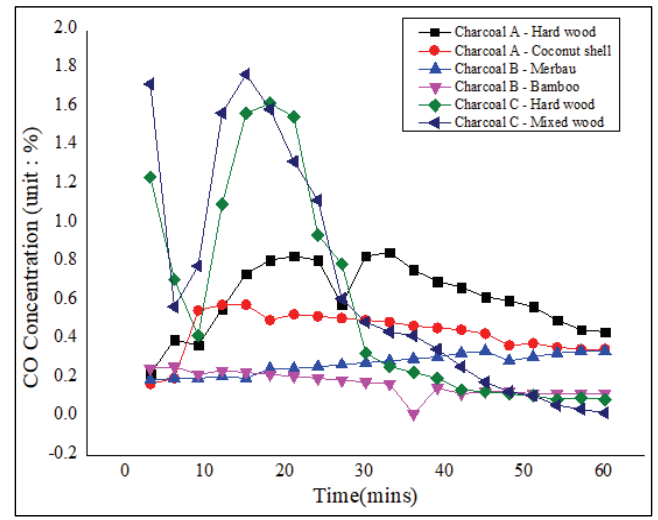

Fig. 2. $\mathrm{CO}$ emission of all test pieces.

of fixed carbon when compared to the carbon element, and a low volatile matter content, leading to little absolute amount of $\mathrm{CO}$ that can be generated due to oxidation of carbon during combustion. In addition, Charcoal $\mathrm{C}$ showed a rapidly high $\mathrm{CO}$ generation following the sharp rise and fall of the initial $\mathrm{CO}$ generation due to sawdust and sulfur as the complexing agent settled on the surface, and incomplete combustion during the process of spreading fire on the sample. The amount of $\mathrm{CO}$ generated was closely related to the content of fixed carbon relative to the preceding carbon element and volatile matter content, and the higher the carbon element excluding the fixed carbon and the higher the content of volatile matter, the higher the amount of $\mathrm{CO}$ generated.

Table 5. Results of heavy metal content about agglomerated wood charcoal

\begin{tabular}{cccccccccc}
\hline Test details & $\begin{array}{c}\mathrm{As} \\
(\mathrm{mg} / \mathrm{kg})\end{array}$ & $\begin{array}{c}\mathrm{Cd} \\
(\mathrm{mg} / \mathrm{kg})\end{array}$ & $\begin{array}{c}\mathrm{Cr} \\
(\mathrm{mg} / \mathrm{kg})\end{array}$ & $\begin{array}{c}\mathrm{Cu} \\
(\mathrm{mg} / \mathrm{kg})\end{array}$ & $\begin{array}{c}\mathrm{Pb} \\
(\mathrm{mg} / \mathrm{kg})\end{array}$ & $\begin{array}{c}\mathrm{Hg} \\
(\mathrm{mg} / \mathrm{kg})\end{array}$ & $\begin{array}{c}\mathrm{Ni} \\
(\mathrm{mg} / \mathrm{kg})\end{array}$ & $\begin{array}{c}\mathrm{Zn} \\
(\mathrm{mg} / \mathrm{kg})\end{array}$ & $\begin{array}{c}\mathrm{Ba} \\
(\%)\end{array}$ \\
\hline \hline Charcoal A (Mixed Hard wood) & N.D. & N.D. & 6 & 43 & 1 & N.D. & 6 & 25 & 2.8 \\
Charcoal A (Coconut shell) & N.D. & N.D. & 20 & 38 & 52 & N.D. & 8 & 117 & 0.2 \\
Charcoal B (Merbau) & N.D. & N.D. & 2 & 9 & 1 & N.D. & 1 & 41 & - \\
Charcoal B (Bamboo) & N.D. & N.D. & 3 & 9 & 1 & N.D. & 1 & 42 & - \\
Charcoal C (Mixed Hard wood) & N.D. & N.D. & 15 & 35 & 19 & N.D. & 7 & 96 & - \\
Charcoal C (Mixed wood) & N.D. & N.D. & 12 & 35 & 15 & N.D. & 6 & 92 & - \\
\hline
\end{tabular}

* Charcoal A - agglomerated wood charcoal powder, Charcoal B - agglomerated wood charcoal sawdust, Charcoal C agglomerated wood charcoal for igniting nine-holed charcoal 


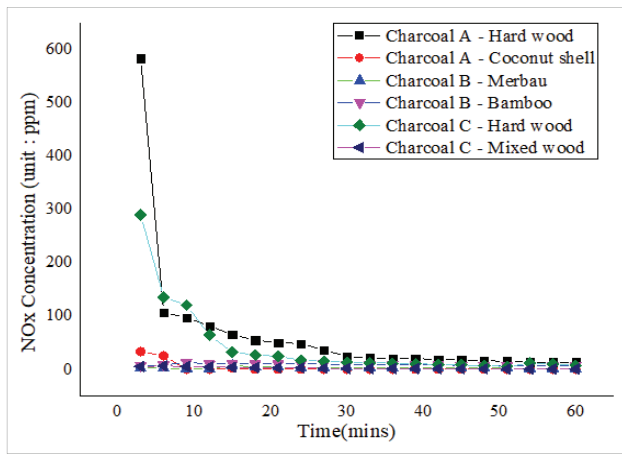

Fig. 3. $\mathrm{NO}_{\mathrm{x}}$ emission of all test pieces.

\subsubsection{Amount of nitrogen oxide $\left(\mathrm{NO}_{x}\right)$ and sulfur oxide $\left(\mathrm{SO}_{x}\right)$ generated by the test piece}

The results of comparison the generation of nitrogen oxides and sulfur oxides according to the type of agglomerated wood charcoal are shown in Figs. 3, 4. As shown in the figure, the average hourly rate of $\mathrm{NO}_{\mathrm{x}}$ generation is $65.5 \mathrm{ppm}$ (Mixed Hard wood) and $2 \mathrm{ppm}$ (Coconut shell) for Charcoal A, 2.6 ppm (Merbau) and $8.7 \mathrm{ppm}$ (Bamboo) for Charcoal B, and $41.3 \mathrm{ppm}$ (Mixed Hard wood) and 41ppm (Mixed wood) for Charcoal C. Among them, in the case of Charcoal A (Mixed Hard wood), the high amount of NOx is generated due to incomplete combustion during initial combustion, resulting in an increase in average amount of generation.

In the case of $\mathrm{SO}_{\mathrm{x}}$ emissions, it was not detected in the agglomerated wood charcoal produced with mixed hardwood species, and $1.8 \mathrm{ppm}$ was detected in the product made with coconut shell. No detection occurred

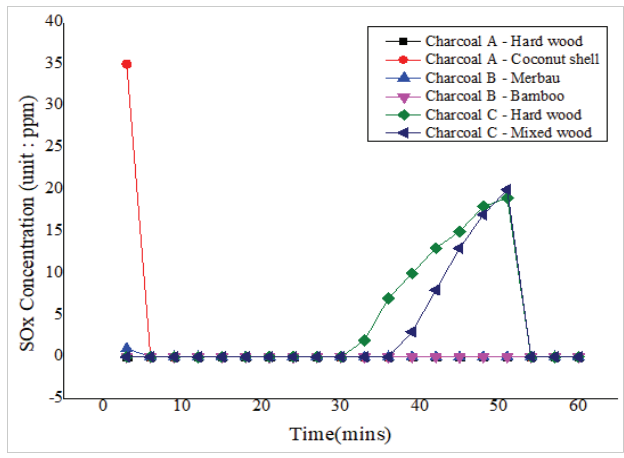

Fig. 4. $\mathrm{SO}_{\mathrm{x}}$ emission of all test pieces.

in charcoal B for both species, and it was $4.2 \mathrm{ppm}$ (Mixed Hard wood) and 3 ppm (Mixed wood) for Charcoal C. Although a trace amount was generated in Charcoal $\mathrm{C}, \mathrm{SO}_{\mathrm{x}}$ emissions in the entire test piece are negligible. In addition, the phenomenon in which $\mathrm{SO}_{\mathrm{x}}$ emission recording occurs mainly after 30 minutes is due to the condensate that is generated due to the temperature deviation when moisture in the gas or high temperature heat in the combustion chamber is sucked into the gas sampling hose, when measuring in a place with the emission of high temperature heat, such as a chimney, due to the properties of the analysis equipment.

\subsection{Comparative analysis of annual average accumulated emissions of air pollutants}

According to the statistics on air pollutant emissions

Table 6. Average of yearly accumulated gross air pollutants emissions for 5 years from 2012 to 2016.(National Air Pollutants Emission Service, 2015-2016)

\begin{tabular}{ccccc}
\hline & Year & $\mathrm{CO}$ & $\mathrm{NO}_{\mathrm{x}}$ & $\mathrm{SO}_{\mathrm{x}}$ \\
\hline \hline \multirow{2}{*}{ Average of yearly gross emissions } & 2015 & 792,776 & $1,157,728$ & 352,292 \\
(unit : ton) & 2016 & 759,044 & $1,248,309$ & 358,951 \\
& Average & 775,910 & $1,203,019$ & 355,622 \\
& 2015 & 232,455 & 8,883 & 79 \\
Average of yearly emissions based & 2016 & 233,066 & 9,059 & 78 \\
on biological combustion & & 232,761 & 8,971 & 78 \\
(unit : ton), For 2 years & Average & (30\% of gross emission) (1\% of gross emission) $(0.02 \%$ of gross emission) \\
\hline
\end{tabular}


released by the National Institute of Environmental Science and Technology, Table 6 shows the annual average amount of air pollutants generated from 2015 to 2016 and the annual average amount of biomass burning. As shown in the table, among the total air pollutant emissions, biomass burning emissions account for $30 \%$ of $\mathrm{CO}, 1 \%$ of $\mathrm{NO}_{\mathrm{x}}$, and $0.02 \%$ of $\mathrm{SO}_{\mathrm{x}}$ and carbon monoxide emissions accounted for a significant portion among the emissions of various air pollutants.

Among these, the air pollutants emitted during the combustion of agglomerated wood charcoal were calculated in consideration of the production and import distribution of the agglomerated wood charcoal. As shown in Table 7, $\mathrm{CO}, \mathrm{NO}_{\mathrm{x}}$, and $\mathrm{SO}_{\mathrm{x}}$ were predicted to account for approximately $0.01 \%, 0.005 \%$, and $0.01 \%$ of emissions due to biomass burning, respectively. The calculation of this is as follows. 4,368 tons of production distribution of agglomerated wood charcoal and 37,215 tons of imported distribution were combined (41,583 tons), and the cumulative amount of $\mathrm{CO}, \mathrm{NO}_{\mathrm{x}}$, and $\mathrm{SO}_{\mathrm{x}}$ generated per hour, which was obtained in this study, is multiplied by the minimum measured value of $170 \mathrm{ppm}, 2 \mathrm{ppm}, 1.8 \mathrm{ppm}$, and the maximum measured value of $615 \mathrm{ppm}, 65.5 \mathrm{ppm}, 4 \mathrm{ppm}$, respectively. In this process, the ranges of $\mathrm{NO}_{\mathrm{x}}$ and $\mathrm{SO}_{\mathrm{x}}$ were omitted because the differences between the minimum and maximum measurements were not large. As the interest

Table 7. Average of yearly accumulated air pollutants emissions based on Charcoal combustion for 2 years from 2015 to 2016

\begin{tabular}{lccc}
\hline & $\mathrm{CO}$ & $\mathrm{NO}_{\mathrm{x}}$ & $\mathrm{SO}_{\mathrm{x}}$ \\
\hline \hline $\begin{array}{l}\text { Average of yearly } \\
\text { emissions based on }\end{array}$ & $7-25$ & 0.47 & 0.01 \\
$\begin{array}{l}\text { Charcoal combustion } \\
\text { (unit : ton) }\end{array}$ & & & \\
The ratio of emission \\
(charcoal/biological \\
$\quad$ under & $0.01 \%$ & $0.005 \%$ & $0.01 \%$ \\
\hline * $\begin{array}{lll}\text { It is multiplied by the amount of charcoal from pro- } \\
\text { duction and import and emission per ton of air pollutants }\end{array}$ \\
those are analyzed in this study.
\end{tabular}

from the public in air pollutants generated during biomass burning increases, attention should be paid to $\mathrm{CO}$ generated during the burning of agglomerated wood charcoal. In particular, future studies are needed on the reduction of $\mathrm{CO}$ generation in Charcoal $\mathrm{A}$ and Charcoal C, which were generated in large amounts.

\section{CONCLUSION}

This study selected three species of agglomerated wood charcoal distributed in Korea, agglomerated wood charcoal powder (Charcoal A), agglomerated wood charcoal sawdust (Charcoal B), and agglomerated wood charcoal for igniting nine-holed charcoal (Charcoal C), among fuel-type wood products. Fuel specificity, hazard material contents and air pollutant emissions generated during combustion based on the products were comparatively analyzed, and the following results were derived.

1. As for fuel specificity of the agglomerated wood charcoal, fixed carbon and ash are inversely proportional, whereas fixed carbon and highcalorific value are proportional. Since Charcoal $B$ has a higher fixed carbon content than Charcoal A, the proportion of fixed carbon in the carbon element is large and the amount of CO generated is low due to the small amount of carbon volatilized.

2. Comparing with the emissions standards of the Air Quality Conservation Act (as of 2019-carbon monoxide: $200 \mathrm{ppm}$ or less (biomass and wood pellet facilities), nitrogen oxides: 150 ppm (biomass and wood pellet facilities), compared with sulfur oxides: $100 \mathrm{ppm}$ (drying and heating facilities among general solid fuel product manufacturing facilities)), the emissions in this study for the air pollutants generated during the burning of agglomerated wood charcoal did not meet the emission standards of nitrogen oxides and sulfur 
Study on Fuel Specificity and Harmful Air Pollutants Factor of Agglomerated Wood Charcoal

oxides in all products. However, the $\mathrm{CO}$ emissions of Charcoal $\mathrm{A}$ and Charcoal $\mathrm{C}$ exceeded the standard values.

3. Currently, there are no emission regulations for air pollutants generated during combustion of agglomerated wood charcoal, but the calculation of the emission coefficients for air pollutants generated by agglomerated wood charcoal kilns, roasters when using white charcoal, and wood stoves for wood pellets has been established. However, there are only few studies on emission control for agglomerated wood charcoal that is frequently used for roasting and as camping fuel. Based on the analysis of combustion gas generated during combustion derived from this study, future research is needed for comparing with the emission standards of pellets, which are wood products for fuel, among the existing biomass burning standards and for reducing carbon monoxide generated during incomplete combustion of agglomerated wood charcoal.

\section{ACKNOWLEDGMENT}

This study was carried out with the support of 'R\&D Program for Forest Science Technology (Project No. "2018117B10-1920-AB01)' provided by Korea Forest Service(Korea Forestry Promotion Institute).

\section{REFERENCES}

Edoardo, M., Park, S.K., Park, J.H. 2019. Carbonaceous Aerosols Generated from Wood Charcoal Production Plants in the South Korea Context. Journal of the Korean Wood Science and Technology 47(3): 277-289.

Jang, J.H., Park, S.H., Lee, M., Lee, S.M., Fauzi, F., Kim, N.H., Park, S.B. 2017. Physical and Fuel Characteristics of Tropical (Indonesia) Bamboo
Charcoal According to Carbonization Temperature. 2019 proceedings of the Korean Society of Wood Science and Technology Annual Meeting, pp. 109. Jo, G.U., Seo, D.J., Kim, S.H., Kim, N.H., Seo, G.Y., Bae, S.J., Cho, Y.G. 2019. Study on the Measurement Process of Particulate Matter and the Improvement of Emission Allowance Standard in Air Discharge Facility. Journal of Environmental Policy and Administration 27(1): 79-106.

Jo, T.S., Lee, O.K., Ahn, B.J., Choi, J.W. 2006. Some Physical Properties and Adsoptive Behaviors of Wood Charcoal Carbonized with Domestic Wood. J. Kor. For. En. 25(1): 9-17.

Kang, S.B., Choi, K.S., Lee, H.H., Han, G.S. 2018. Analysis of Emission Characteristics and Emission Factors of Carbon Monoxide and Nitrogen Oxide Emitted from Wood Pellet Combustion in Industrial Wood Pellet Boilers Supplied According to the Subsidy Program of Korea Forest Service Sea. Journal of the Korean Wood Science and Technology 46(5): 597-609.

Kim, D.Y. 2011. Analysis of Air Pollutants Emissions from Biomass Burning in Seoul Metropolitan Area. Research report of Gyeonggi Research Institute pp. $1-128$.

Kim, S.K. 2010. Evaluation of wood waste management practice in Ulsan by life cycle assessment. Master's thesis, University of Ulsan, Korea.

Korea Forest Service. 2017. Market research of wood products pp. 51, 173.

Korean Standards Association. Method for proximate analysis of coal and coke, KS E 3705. 2001.

Kwon, G.J., Kwon, S.M., Cha, D.S., Kim, N.H. 2010. Characteristics of Pellet Prepared from Sawdust and Wood-tar. Journal of the Korean Wood Science and Technology 38(1): 36-42.

Kwon, G.J., Kim, A.R., Lee, H.S., Lee, S.H., Hidayat, W., Febrianto F., Kim, N.H. 2018. Characteristics of White Charcoal Produced from the Charcoal Kiln 
for Thermotherapy. Journal of the Korean Wood Science and Technology 46(5): 527-540.

Lee, C.G., Kang, S.G. 2015. A Study on Fuel Characteristics of Mixtures Using Torrefied Wood Powder and Waste Activated Carbon. Journal of the Korean Wood Science and Technology 43(1): 135-143.

Lee, C.G., Kim, H.G. 2000. A Numerical Study on the Coal Particle Combustion Characteristics Usin Mulit Reaction and Single Flame Surface Model.

Lee, J.A., Shim, K.B., Chio, Y.S., Ahn, B.L. 2017. Factor affecting the willingness to pay on the quality-indicated wood products. Korean Journal of Agricultural Economics 58(4): 67-86.

National Air Pollutants Emission Service, 2015-2016 (http://airemiss.nier.go.kr/module/statistics/causeSt atistics.do?siteId=airemiss\&id=airemiss_0303000 00000)

Park, S.K., Chio, S.J., Kim, J.Y., Lee, H.J., Jang, Y.K.,
Bong, C.K., Kim, J.H., Hwang, U.H. 2011. A Study on the Development of Particulate Matters Emission Factors from Biomass Burning: Mainly Commercial Meat Cooking. Journal of Korean Society for Atmospheric Environment 27(4): 426-435.

Seo, J.M. Kim, J.Y. 2015. GHS Emission from the Charcoal Use in Household Sector. The Journal of the Korean Economy pp. 1-25.

Yang, I., Han. G.S. 2018. Comparison of Domestic and Overseas Allowable Standards Related to Emissions from Wood Pellet Combustion. Journal of the Korean Wood Science and Technology 46(5): 553-564.

Yang, B.S., Yang, J.W., Kim, D.Y., Kim, J.K., Hwang, W.J., Kwon, G.J. 2017. Characteristics of Wood Tar Produced as Byproduct from Two Types of The Kiln in The Manufacture of Oak Charcoal. Journal of the Korean Wood Science and Technology 45(6): 772-786. 


\title{
APPENDIX
}

\author{
(Korean Version)
}

\section{시중에 유통되고 있는 성형목탄의 연료특성과 유해인자에 대한 연구}

초록 : 본 연구에서는 연료형 목재제품 중 국내 유통되고 있는 3 종의 성형탄(숯가루 성형탄, 톱밥성형탄, 구멍탄착화용 성형탄)을 선정하여 연소특성, 유해물질 함량, 연소 시 발생되는 대기오염물질 배출 특성에 관한 연구를 진행하였다. 연소 시 솣가루 성형탄이 톱밥성형탄보다 더 높은 일산화탄소를 발생시켰으며, 성형목탄의 연소 시 발생하는 대기오염물질 배출 량을 대기환경보전법 배출허용기준과 비교 시 전체 제품의 질소 - 황산화물 배출 기준에 미치지 못하였다. 2019년 기준 배출 허용기준으로 일산화탄소 $200 \mathrm{ppm}$, 질소 산화물 $150 \mathrm{ppm}$, 황산화물 $100 \mathrm{ppm}$ 이며, 이산화탄소 배출 기준은 변경되지 않았 다. 본 연구에 의해 생성된 연소가스 분석을 기초 자료로 성형목탄의 연소 시 생성되는 대기오염물질의 배출 계산을 위한 표준에 대한 연구 및 성형목탄의 불완전 연소에 의해 생성되는 일산화탄소 저감에 대한 추가적인 연구가 필요할 것으로 판단된다.

\section{1. 서 론}

최근 국내에 유입되는 미세먼지 및 대기 중의 오염물질에 대한 국민들의 관심도가 높아지고 있으며(Jo et al., 2019), 환경부는 대기환경보전법 시행규칙을 개정하고, 2019년 5월 공포하였으며, 2020년 1월 시행을 앞두고 있다. 이 시행규칙의 주요 사항은 에틸벤젠, 스틸렌, 사염화탄소 등과 같은 물질을 특정대기유해물질로 신설하였으며, 기존의 특정대기유해물질(크롬, 비소, 수은 등 13 종)은 약 $33 \%$ 강화되었다. 일반대기오염물질 11 종(먼지, 일산화탄소, 질소산화물, 황산화물 등)에 대해서는 평균 $30 \%$ 저감된 배출허용기준을 제시하였다(Magnone et al., 2019).

이처럼 대기오염물질 배출허용 기준이 강화됨에 따라 산업체는 대기오염물질 배출 저감 장치 구축, 석탄발전소는 저탄장 옥내화(야외 저탄장 비산먼지 저감을 위한 옥내화 사업) 등의 방식과 신재생에너지원인 목재펠릿 등의 사용을 대안으로 취하고 있으며(Kang et al., 2018; Yang et al, 2018), 최근 캠핑객의 중가로 인하여 국내에서 사용량이 증가하고 있는 성형목탄 등에 대해서도 연료형 목재제품에 대한 연구를 위해 폐목재 및 폐활성탄 등 혼합형 고형연료 등이 자원의 지속적 사용을 위한 연구가 진행되고 있다.(Kwon et al., 2010; Lee et al., 2015) 그러나, 이러한 연료형 목재제품에 사용이 금지된 폐목재를 사용하여 벤젠, 톨루엔 및 일산화탄소와 같은 유해가스가 발생하는 사례가 빈번하게 발생되고 있다(Kwon et al., 2018; Yang et al., 2018; Edoard et al., 2019).

이를 방지하기 위하여『목재의 지속가능한 이용에 관한 법률』의 시행령 제 14 조 제 1 항에 의거하여 15 가지로 목재제품을 대상으로 산림청에서는 지속적인 단속 및 제품의 시험의뢰를 통해 품질 검사로 적합여부에 따른 행정 사법절차를 진행해 오고 있다. 특히, 목재펠릿, 성형목탄 등 연료형 목재제품은 현행 품질기준 항목으로는 제품에 포함된 중금속 함량과 발열량 등에 따라 품질을 평가하게 되어 있다(Lee et al., 2017).

그러나 대기오염물질 배출허용 기준은 단순한 기준의 강화뿐 아니라 2011년 대기오염물질 배출원 중 생체연소를 포괄적으로 의미하는 용어인 생물성연소(고기 및 생선구이, 노천소각, 목재난로, 숯가마 등에서 대기로 배출되는 오염물질)를 그 범위에 포함하게 되었다.

생물성연소 시 다양한 입자상, 가스상 대기오염물질 배출뿐만 아니라 이산화탄소, 메탄, 아산화질소 등 온실가스도 대규모 로 배출(Kim, 2011)되며, 음식점과 캠핑장 등에서 많이 사용되는 성형목탄에 대한 연소 시 대기오염물질 배출에 관심 증가와 고기구이를 대상으로 미세먼지 배출에 대한 연구가 진행되고 있다(Park et al., 2011).

그러나 성형목탄, 목재 펠릿과 같은 연료형 목재제품 연소 시 발생되는 대기오염물질에 대한 연구는 미비하며, 특히, 목재를 소재로 한 연료에 관한 연구는 폐목재 소각 시 대기오염물질 발생 저감에 대한 연구와 목탄을 대상으로 수종 및 제품에 따른 온실가스 연평균 배출량 산정에 관한 연구가 전부이다(Kim et al., 2010; Seo et al., 2015; Yang et al., 2017).

이에 본 연구는 대기오염물질 배출허용기준 강화 및 생물성연소에 대한 중요성 부각되는 지금의 시점에서 성형목탄의 대기오 염물질 배출 기준 마련을 위해 국내 유통되고 있는 성형목탄 제품 간 품질 특성과 연소 시 발생되는 대기오염물질 $\left(\mathrm{CO}, \mathrm{NO}_{\mathrm{x}}\right.$, $\mathrm{SO}_{\mathrm{x}}$ ) 배출량을 비교분석하고자 한다. 


\section{2. 재료 및 방법}

\section{1. 공시재료}

본 연구에 사용된 공시재료는 목재제품의 규격과 품질기준 고시(제2018-8호)에 따른 목재제품 국내 유통되고 있는 3종의 성형목탄을 대상으로 제재업4종(국내 생산)과 목재수입유통업(수입)으로 분류하여 수종에 구분이 되었다. 분류된 성형목탄 시료의 종류별 수종은 Table 1과 같다. Charcoal A(Mixed Hard wood)는 (주홈베큐, Charcoal A(Coconut shell)은 주원시스템, Charcoal B(Merbau)는 신일에너지, Charcoal B(Bamboo)는 (주)우애 참솣코리아, Charcoal C(Mixed Hard wood)는 용문산업, Charcoal C(Mixed wood)는 (쥐대명차콜에서 공수하였다.

\section{2. 실험방법}

\subsection{1. 시험편의 연료특성}

공시재료의 연료적 특성비교를 위해 발열량, 고정탄소, 휘발분을 분석하였다. 발열량 중 전건원료를 이용한 고위발열량을 측정하기 위해 봄베형 열량계(Bomb Calorimeter, Parr 6400, PARR INSTRUMENT INC, USA)를 이용하였으며, 고정탄소, 휘발분, 회분의 구성성분 분석을 위하여 KS F 3705 (석탄류 및 코크스류의 공업분석방법)에 의거하여 수분, 휘발분, 회분, 고정탄소율의 구성성분 분석을 실시하였다. 시험편의 탄소, 수소 구성 분석을 위하여 자동원소분석기(Automatic Elemental Analyzer, Flash 2000, Thermo SCIENTIFIC, USA)를 이용하였다.

\subsection{2. 시험편의 유해물질 함량}

성형목탄의 연소 시 대기 중으로 발생될 대기오염물질의 예측을 위하여 시험편 내에 함유된 제품의 유해물질인 중금속 8 종과 질산바륨과 같은 소량의 유해물질은 유도결합플라즈마분광계(JP/ICPE-9820, Shimadzu, Japan)를 이용하였다. 전처리 방법으로는 시료를 40 메쉬 $(0.25 \mathrm{~mm})$ 이하의 입자 $0.25 \mathrm{~g}$ 을 선별하여 $70 \%$ 질산용액을 시료 무게 대비 240 배 증류수 희석을 하고, 마이크로파 분해 시스템(Microwave, Multiwave PRO, Anton Parr, Austria)으로 30 분 승온, 30 분 $170^{\circ} \mathrm{C}$ 온도 유지를 통해 시료 전처리를 하였다. 본 연구에서는 소량의 시료 $(0.25 \mathrm{~g})$ 로 진행하여 잔여 시료 없이 모두 용해되었다.

\subsection{3. 시험편의 대기오염물질 발생량}

성형목탄 제품에 따른 연소 시 발생되는 대기오염물질을 비교하기 위하여 Fig. 1 과 같은 시중에 판매되고 있는 $40 \times 40 \times 80$ $\mathrm{cm}$ 크기의 연탄 화로를 선정하여 실대재 연소 시 사용하였다. 화로 내부에 $330 \mathrm{~g}$ 의 시험편을 설치하였으며, 착화시점(착화온도 $\left.250^{\circ} \mathrm{C}\right)$ 부터 목재제품의 규격과 품질기준 고시(제2018-8호)에 의거하여 착화성 측정시간인 60 분간 배출되는 대기오염물질(ppm, $\%$ )을 측정하였다. 이때, 측정한 대기오염물질은 $\mathrm{CO}, \mathrm{NO}_{\mathrm{x}}, \mathrm{SO}_{\mathrm{x}}$ 4가지를 측정하였으며, 대기배출가스측정기(Portable combustion flue gas analyzer, GreenLine MK2, EUROTRON s.r.l, Italy)를 이용하였다.

\section{3. 결과 및 고찰}

국내 유통되는 성형목탄의 종류별 2가지를 선정하여 제품의 품질특성과 연소 시 발생되는 대기오염물질 배출량을 측정하였으 며, Table 3의 목재제품 규격품질 기준에 의하여 품질검사를 하였고, Table 4에 따른 대기오염물질 배출허용 기준에 근거하여 성형목탄 연소 시 발생되는 대기오염물질 발생량과의 비교분석을 통하여 결과를 도출하였다.

\section{1. 시험편의 연료 특성}

목재제품의 규격과 품질기준 고시(제2018-8호) 중 부속서 14에 의한 시험법으로 발열량, 고정탄소, 휘발분, 원소분석 결과는 Table 2에 나타냈다. 성형목탄 제품 중 Charcoal A (Mixed Hard wood), Charcoal C (Mixed Hard wood), Charcoal C (Mixed wood)은 회분 함량 $30 \%$ 이상이며, 고정탄소 $42 \%$ 이하로 나타났는데, 이는 제탄 및 제조 과정에서 유입된 흙, 토양과 같은 물질이 제거되지 않은 상태의 원재료를 이용하여 성형되어 회분 함량이 높은 것으로 판단된다. 그리고 함수율과 회분 함량이 $10 \%$ 이하로 시험편 중 가장 낮으며, 7,600 kcal $/ \mathrm{kg}$ 이상으로 높은 고위발열량의 품질을 가진 두 수종의 Charcoal $\mathrm{B}$ 는 원재료가 열대수종인 Merbau와 Bamboo를 사용하여 우수한 연료적 특성을 나타내는 것으로 사료된다(Jang et al., 2017). 실험을 통해 성형목탄의 고위발열량과 고정탄소 함량은 비례관계로 나타났으며, 이는 탄화과정에서 탄화도가 높아질수록 휘발분 함량은 감소하고 이와 역수관계인 고정탄소 함량과 잔류 무기물이인 회분함량이 높아지는 것으로 사료되며(Lee et al., 2015), 또한 
Study on Fuel Specificity and Harmful Air Pollutants Factor of Agglomerated Wood Charcoal

고정탄소 함량이 높을수록 발열량도 높아지는 것으로 나타났다. 이는 시료의 총질량은 휘발분의 휘발(휘발분)과 char의 반응(고 정탄소변형), 수분 증발(함수율), ash(잔류 회분)의 합으로 계산할 수 있기 때문이다(Lee et al., 2000). 수소 및 산소함량이 감소되기 때문에 원재료의 탄화도와 밀접한 관련을 나타냈다(Jo et al., 2006). Charcoal A (Coconut shell)의 경우, 원소분석의 Carbon (\%) 함량이 Fixed carbon (\%) 함량보다 낮은 이유는 원소분석 과정에서 전건상태의 시료를 분석하는 반면 공업분석의 과정에서는 기건상태의 시료로 분석을 하여, 함유된 $20.8 \%$ 의 함수율 차이로 인해 고정탄소의 탄소원소 역전현상을 나타나게 하는 것으로 판단된다.

\section{2. 시험편의 유해물질 함량}

시험편 내에 함유된 유해물질인 중금속, 질산바륨 등의 함량 결과는 Table 3에 나타냈다. Table 4와 비교하여 Charcoal $\mathrm{A}$ 와 Charcoal $\mathrm{C}$ 의 각 두 수종 모두에서의 $\mathrm{Cu}$ 함량과 Charcoal A (Coconut shell)에서의 $\mathrm{Pb}$ 함량이 기준치를 초과하였고, 이는 성형목탄 제조 및 재료 전처리 과정 등에서 발생할 수 있는 기준치 이상의 미량 중금속 검출로 판단된다. 나머지 모든 제품에서는 $\mathrm{As}, \mathrm{Cd}, \mathrm{Hg}$ 의 미검출 및 $\mathrm{Ni}, \mathrm{Zn}$ 함량의 기준치 이하 결과가 검출 되었다. Charcoal A 두 수종에서 $\mathrm{Ba}(\%)$ 이 검출된 이유는 숯가루성형탄(Charcoal A) 제품 특성상 초기 착화를 촉진하기 위해 성형목탄 시료 무게 대비 $30 \%$ 이내의 질산바 륨 첨가를 허용하고 있기 때문이다.

\section{3. 시험편의 대기오염물질 발생량}

3.3.1. 시험편의 일산화탄소 $(\mathrm{CO})$ 발생량

Fig. 2 는 성형목탄의 종류에 따른 일산화탄소와 이산화탄소의 발생량 비교를 한 결과이다. $\mathrm{CO}$ 의 시간당 평균 발생량은 Charcoal A이 0.0615\% (615 ppm) (Mixed Hard wood), 0.0433\% (433 ppm) (Coconut shell), Charcoal B는 0.0279\% (279 ppm) (Merbau), 0.017\% (170 ppm) (Bamboo), Charcoal C는 0.0586\% (586 ppm) (Mixed Hard wood), 0.0589\% (589 ppm) (Mixed wood)으로 나타냈다. Table 5에 나타난 바와 같이 두 수종의 Charcoal $\mathrm{A}$ 는 유기 물질과 혼합 시 폭발성 혼합물을 형성하는 착화제로 질산바륨이 교반되어 있어 Charcoal C에 비해 높은 완전연소로 $\mathrm{CO}$ 배출량이 낮고, Charcoal A(Coconut shell)의 수분량이 $20.8 \%$ 로 Charcoal A (Mixed Hard wood)보다 더 많기 때문에 착화까지 시간이 더 걸린 것을 높아지는 $\mathrm{CO}$ 발생량으로 확인할 수 있으며, $7.5 \%$ 의 낮은 휘발분 함량으로 평균 $\mathrm{CO}$ 발생량의 차이를 보인다. 두 수종의 Charcoal B의 경우, Charcoal A, Charcoal C에 비하여 CO 배출량이 현저히 적은 것으로 나타나는데, 이는 Charcoal B의 탄소원소 대비 고정탄소의 비중이 높고 휘발분 함량이 낮아 연소 시 탄소가 산화되어 $\mathrm{CO}$ 가 생성될 수 있는 절대량이 적기 때문에 나타난 측정값이다. 그리고 Charcoal $\mathrm{C}$ 는 표면부에 안착된 착화제 역할로의 톱밥과 황으로 인해 초기 $\mathrm{CO}$ 발생량의 급격한 등락과 이후 시료에 불이 옮겨 붙는 과정에서 불완전연소가 일어나 급격히 높은 $\mathrm{CO}$ 발생량을 보이게 되었다. $\mathrm{CO}$ 의 발생량은 앞선 탄소원소 대비 고정탄소의 함량과 이를 포함한 휘발분 함량과 밀접한 관련을 나타냈으며 고정탄소를 제외한 탄소원소가 높고 휘발분 함량이 높을수록 $\mathrm{CO}$ 의 발생량이 증가하는 결과를 도출하였다.

3.3.2. 시험편의 질소산화물 $\left(\mathrm{NO}_{\mathrm{x}}\right)$, 황산화물 $\left(\mathrm{SO}_{\mathrm{x}}\right)$ 발생량

Fig. 3, 4는 성형목탄의 종류에 따른 질소산화물과 황산화물의 발생량을 비교한 결과이다. 그림에 나타난 바와 같이, $\mathrm{NO}_{\mathrm{x}}$ 의 시간당 평균 발생량은 Charcoal A은 $65.5 \mathrm{ppm}$ (Mixed Hard wood), $2 \mathrm{ppm}$ (Coconut shell), Charcoal B은 2.6 ppm (Merbau), $8.7 \mathrm{ppm}$ (Bamboo), Charcoal C는 $41.3 \mathrm{ppm}$ (Mixed Hard wood), $41 \mathrm{ppm}$ (Mixed wood)의 결과를 나타냈다. 이 중 Charcoal A (Mixed Hard wood)의 경우 초기 착화 시 불완전연소로 인해 발생하는 $\mathrm{NO}_{\mathrm{x}}$ 의 양이 높아 평균 발생량 증가로 나타났다.

$\mathrm{SO}_{\mathrm{x}}$ 배출량의 경우 Charcoal A 중 활엽수혼합수종으로 제조한 성형목탄은 미검출, Coconut shell로 제조한 제품은 1.8 $\mathrm{ppm}$, Charcoal B는 2수종 모두 미검출, Charcoal C는 $4.2 \mathrm{ppm}$ (Mixed Hard wood), 3 ppm (Mixed wood)이 배출되어, Charcoal $\mathrm{C}$ 에서 미량 발생된 것으로 나타났지만 전체 시험편에서 $\mathrm{SO}_{\mathrm{x}}$ 의 배출량은 미비한 수준이다. 그리고 $\mathrm{SO}_{\mathrm{x}}$ 배출량 기록이 30 분 이후에 주로 나타나는 현상은 분석기기 특성상 굴뚝과 같이 고온의 열이 방출되는 곳에서 측정 시 가스상의 수분, 또는 연소실 안 고온의 열이 가스 샘플링 호스로 흡입되면서 온도 편차에 의해 생기는 응축수 때문인 것으로 생각된다.

\section{4. 대기오염물질의 평균 연 누적 배출량 비교 분석}

국립환경과학원에서 발표한 대기오염물질 배출량 통계 자료에 의하여 2012년부터 Table 6는 2015년부터 2016년까지 2년간 
의 국내 대기오염물질 연평균 총 발생량 자료와 생물성연소의 연평균 발생량을 나타낸 자료이다. 자료에 나타난 바와 같이 전체의 대기오염물질 배출량 중 생물성연소에 의한 배출량은 $\mathrm{CO} 30 \%, \mathrm{NO}_{\mathrm{x}} 1 \%, \mathrm{SO}_{\mathrm{x}} 0.02 \%$ 를 차지하며, 여러 대기오염물질 배출가스 중 일산화탄소의 배출량이 상당부분을 차지하였다.

이 중, 성형목탄의 생산수입 유통량을 고려하여 성형목탄 연소 시 배출되는 대기오염물질을 산정한 결과, Table 7와 같이 생물성연소로 인한 배출량 중 $\mathrm{CO}$ 약 $0.01 \%, \mathrm{NO}_{\mathrm{x}} 0.005 \%, \mathrm{SO}_{\mathrm{x}} 0.01 \%$ 이하로 배출되는 것으로 예측되었다. 이를 환산하는 과정은 성형목탄의 생산 유통량 4,368 ton과 수입 유통량 37,215 ton(목재제품의 생산수입유통 시장조사 보고서. 2017. page 51. page 173, 2015-2016년 평균)을 합하여(41,583 ton) 본 연구를 통해 도출된 시간당 누적 $\mathrm{CO}^{\circ}$ 와 $\mathrm{NO}_{\mathrm{x}}, \mathrm{SO}_{\mathrm{x}}$ 의 발생량을 최소 측정치 $170 \mathrm{ppm}, 2 \mathrm{ppm}, 1.8 \mathrm{ppm}$ 과 최대 측정치 $615 \mathrm{ppm}, 65.5 \mathrm{ppm}, 4 \mathrm{ppm}$ 으로 각각 곱하였다. 이 과정에서 $\mathrm{NO}_{\mathrm{x}}$ $\mathrm{SO}_{\mathrm{x}}$ 는 최소측정치와 최대 측정치의 차이가 크지 않음으로 범위를 생략했다.

생물성연소 시 발생되는 대기오염물질의 관심도가 높아짐으로써 성형목탄 연소 시 발생되는 $\mathrm{CO}$ 에 주목해야하며 특히 발생량 이 많았던 Charcoal A와 Charcoal C의 $\mathrm{CO}$ 발생 저감에 대한 연구가 필요할 것으로 판단된다.

\section{4. 결 론}

본 연구는 연료형 목재제품 중 국내 유통되고 있는 성형목탄 3종(숯가루성형탄(Charcoal A), 톱밥성형탄(Charcoal B), 구멍탄 착화용 성형탄(Charcoal C)을 선정하여 제품에 따른 연료 특성, 유해물질 함량, 연소 시 발생되는 대기오염물질 배출량을 비교분석하였으며, 다음과 같은 결과를 도출하였다.

1. 성형목탄의 연료 특성으로 고정탄소와 회분은 반비례, 고정탄소와 고위발열량은 비례의 관계를 나타냈으며, 톱밥성형탄 (Charcoal B)이 솣가루성형탄(Charcoal A)보다 높은 고정탄소 함량을 가지고 있어 탄소원소 중 고정탄소량의 비중이 크게 자리 잡아 나머지 휘발되는 적은 탄소 함량으로 인해 CO 발생량이 낮게 나타났다.

2. 성형목탄의 연소 시 발생하는 대기오염물질 배출량을 대기환경보전법 배출허용기준(2019년도 기준-일산화탄소:200ppm 이하(바이오매스 및 목재펠릿 사용시설), 질소산화물: $150 \mathrm{ppm}$ (바이오매스 및 목재펠릿 사용시설), 황산화물:100ppm(일반 고형연료제품 제조시설 중 건조 및 가열시설))과 비교하면, 전체 제품에서 질소산화물과 황산화물의 배출기준에는 미치지 못하였으나, 숯가루성형탄(Charcoal A)과 구멍탄착화용 성형탄(Charcoal C)의 CO 배출량이 기준치를 초과하는 결과를 나타냈다.

3. 현재 성형목탄 연소 시 발생되는 대기오염물질에 대한 배출규제는 없으나, 생물성연소로 숯가마, 백탄 이용 시 고기구이, 목재펠릿용 화목난로 등에서 발생되는 대기오염물질의 배출계수 산정이 구축되어 있으나 구이용 및 캠핑연료로 많이 사용되는 성형목탄에 대한 배출규제에 대한 연구는 미비하다. 본 연구를 통해 도출된 연소 시 발생되는 연소가스에 대한 분석을 기초로 기존의 생물성연소 기준 중 연료용 목재제품인 펠릿의 배출기준과 비교 가능한 연구와 성형목탄의 불완전연 소 시 발생되는 일산화탄소를 저감시키기 위한 연구가 필요하다. 